\title{
Level of Satisfaction and Issues with Procurement Systems used in the Malaysian Public Sector
}

\begin{abstract}
Since the declaration of Malaysian independence, the public sector has significantly contributed to the country's development. In the 1990s, a new procurement system was developed due to CIBD various changes in the construction industry. Since that period, the poor quality of public sector projects has started to attract public attention. This paper describes a study that was conducted to identify the dominant public procurement systems in place, the problems associated with these systems, and the satisfaction level of the industry players in the Malaysian construction industry. The results were drawn from 84 survey responses and interviews with industry players. The public sector is using a traditional system inherited from the British, with an intention to adopt new procurement systems. Aside from the disputes that are present in most systems, the public sector seems to encounter particular problems in relation to capabilities, time, and cost of the major procurement systems used. Traditional work culture and the industry environment influence public sector practice, which accounts for the modifications of each procurement system used. Thus, the full advantages of using an alternative procurement system may not be realised in public sector organizations. This produces an average level of satisfaction gained from the procurement system adopted. As a developing country, Malaysia needs to exert significant efforts to improve the public procurement system.
\end{abstract}

Keywords: Procurement system, Problem, Satisfaction level, Public sector, Construction industry

\section{Introduction}

Public sector organisations exist for the ultimate benefit of the public citizenry (Gould, 1997). Masteman (2002, p.9) defines the client as "the organization, or individual, who commissions the activities necessary to execute and complete a project in order to satisfy its/his needs and then to enter into a contract with the bespoke parties". The government, as a public sector client, is expected to initiate major developments on social amenity projects in the Malaysian construction industry. For instance, in 2008, from the total annual Malaysian construction project value, educational projects and hospitals contributed approximately 35\% (RM 15 billion $^{1}$ ), followed by infrastructure development projects with a contribution of $20 \%$ (RM 9 billion) (e.g. CIDB, 2009; Ibrahim et al., 2010). The government is an important contributor to the demand for specific industries, especially during an economic slowdown. An example is the Ninth Malaysia Plan from 2006 to 2010, in which the government allocated RM 2.4bn worth of projects to maintain industrial growth.

Ashworth (1991) defined a procurement system as a type of contract that states the obligations, rights, and liabilities of the parties involved, which include clients, consultants, and contractors. On the other hand, Turner (1999) defined procurement as the participation of three important

\footnotetext{
${ }^{1}$ RM approximately AUD 0.31
} 
parties (clients, consultants, and contractors) who work together to provide practical guidance on decisions regarding the actual procurement direction.

Procurement systems are of two types: traditional and alternative. Traditional procurement systems are categorized as Lump Sum-Firm Bill of Quantities (LSFBQ), Lump SumApproximate Bill of Quantities (LSABQ), and Lump Sum-Drawing and Specification (LSDS), whereas alternative procurement systems include the D\&C and Turnkey. According to Ramus et al. (2006), LSBQ is a contract where surveyors prepare a bill of quantities based on the architect's drawing and specification. The quantities and unit rates in the bill of quantities form part of a contract. For LSABQ, whatever quantity mentioned in the LSABQ is is subject to a later adjustment, but the unit rates remain part of the contract document. Contractors are invited to price the bill of quantities and to submit tenders in competition. LSDS procurement only provides drawings to contractors, who then have to prepare their own Bill of Quantities. Each of these categories has its own advantages and disadvantages.

This paper describes a study carried out in order to:

1. identify the dominant public sector procurement systems in use;

2. identify the problems with these dominant public sector procurement systems; and

3. determine the satisfaction levels of stakeholders in the dominant procurement systems.

The following sections describe the results of this study.

\section{Current Dominant Public Procurement Systems}

Public clients have an obligation to spend public money properly by following a set of procedures (Tabish \& Jha, 2011). The awarding of a project is usually based on the lowest responsible and responsive bidder (Jaafar \& Radzi, 2012). Mahmood and Mansor (1996) define public sector clients as government bodies that are directly related to the construction industry, such as the Public Works Department (PWD) and other local and semi-government authorities including the Urban Development Authority and State Economic Development Corporation. The existing procurement system used by the public sector in numerous developing countries has been inherited from their former colonial administrators (e.g. Ofori, 2007; CIDB, 2009). In this respect, Malaysia has inherited its procurement system from the British (Jaafar and Aziz, 2006; CIDB, 2009). In the earlier days of independence, the public sector used a traditional procurement system in project development. A traditional system is one where design and construction are separated, whereas these aspects are performed in parallel in modern systems (Masterman, 2002).

Given the large number of projects needed to support the nation's growth in the mid-1990s, significant changes to the dominant procurement system were applied in the Malaysian construction industry. Since then, Malaysia has adopted a new public sector procurement system (Rashid et al., 2006) to cope with high demand and to achieve faster project completion rates. Various new procurement systems were introduced as alternatives to the traditional procurement system. This move was justified by similar movements in other countries such as the United Kingdom (Davis, 1995) and the United States (El Wardani, 2006 and Hale et al., 2009) to achieve improved project outcomes.

Since the government's initial adoption of new procurement systems such as project management consultancy (PMC); build, operate, and transfer (BOT); and design and construct $(D \& C)$, public project failures have gained widespread media attention. Project performance is generally measured in terms of cost, time, and quality; factors that are influenced by the type of

Jaafar, M and Radzi N M (2013) 'Level of satisfaction and issues with procurement systems used in the Malaysian public sector', Australasian Journal of Construction Economics and Building, 13 (1) 50-65 
procurement system employed (CIOB, 2010). As fast-track procurement systems have become popular in Malaysia, problems related to the performance of the construction industry have emerged, including issues related to quality, productivity, and safety (Rahman et al., 2010). According to Nitithamyong and Tan (2007), the Ministry of Works revealed in 2003 that a number of public projects handled by a few consultancies were not completed within schedule and exhibited poor workmanship. Meanwhile, D\&C and Turnkey system projects, such as the construction of 13 hospitals in the 1990s, were completed, but with numerous defects (Hashim et al., 2006; Jaafar \& Aziz, 2009, Jaafar \& Radzi 2012). Ibrahim et al. (2010) observed that by the end of 2004, major development projects faced problems such as delays in the construction schedule, cost escalation, and even structural defects in schools and community college buildings. The problems were attributed to the PMC system and the PMC system is therefore currently being replaced by the $\mathrm{D} \& \mathrm{C}$ system.

In an attempt to improve the industry, the Construction Industry Development Board (CIDB) launched the Malaysian Construction Industry Master Plan in 2006. Under Strategic Thrust 1, industry services and commercial business entities were encouraged to enhance knowledge, efficiency, and effectiveness. These goals were achieved through the development and improvement of various strategic instruments and the identification of the best procurement practices by managerial tendering and contracting.

\section{The Problems with current Procurement Systems}

According to Toor and Ogunlana (2008), the major problems faced by numerous construction projects are usually caused by an inadequate understanding of the procurement system, lack of resources, discrepancies between design and construction, inadequate project management practices, numerous variation orders, communication lapses, cultural issues, differing interests of participants, poor labour productivity, and lack of skilled contractors. They added that the problem of delays in construction not only results in cost overruns and poor quality, but also in more conflicts.

\section{Stakeholder Satisfaction with Different Procurement Systems}

Liu and Walker (1998) considered satisfaction as an attribute of success. Satisfaction can be described as the level of happiness among the people affected by a project. These people include key project participants, such as the client, architect, contractor, subcontractors, surveyors and engineers, end-users, and third parties (Chan et al., 2002). Torbica and Stroh (2001) believed that if end-users are satisfied, the project can be considered as successfully completed.

Roodhooft and Abbeele (2006) investigated the satisfaction of organisations with the consulting services they buy. The findings supported the results of the multi-attribute selection technique of Skitmore and Marsden (Masterman, 2002), which describes the complete satisfaction of private clients within a conventional system. Masterman (2002) elaborated on the technique implemented by Skitmore and Marsden (1988) by assessing the satisfaction of private clients with the D\&C system. Hashim et al. (1996) found no significant difference in the level of client satisfaction from different procurement routes selected.

\section{Industry Survey}

Following on from the results of the literature review detailed in the previous sections, a survey was carried out among various stakeholders in the Malaysian construction industry. 


\section{Questionnaire Development}

This paper is part of a larger study on the procurement system applied in the Malaysian construction industry. Aside from having questions on the respondent's background, the other parts of this section focus on the problems associated with the usage of the selected procurement types and their satisfaction level. Questions on problems, which were included in the questionnaire, were adopted from various sources and then categorized under different measures, such as legal, management, capability, dispute, time, risk, operation, cost, and quality. The items are listed in Table 2 . In relation to the study on the problem in using procurement, a five-point Likert-scale with options ranging from "strongly disagree" to "strongly agree" has been adopted by Kong et al. (2006), Adnan et al. (2008), and Ling and Poh (2008). For satisfaction, a three-point Likert-scale has been used.

\section{Data Collection}

The questionnaire forms were distributed to 800 respondents (i.e., 300 clients from public and private sectors, 200 contractors, 100 architects, 100 engineers, and 100 quantity surveyors). The respondents were selected randomly. Professional consultants were chosen from the Web sites of the Malaysian Association of Architects (PAM), Institution of Engineers Malaysia (IEM), and the Board of Quantity Surveyors Malaysia (BQSM). For contractors, company names were chosen from the Malaysian CIDB Directory 2008-2009. For private client organizations, the list was obtained from the Real Estate Housing Developers Association (REHDA), whereas federal and state departments have been included to represent public clients. These organizations were selected because they are the actual players in the construction industry, and they have important roles in managing project procurement systems. As explained by Rashid et al. (2006), the process of acquiring a building by a client involves a group of people who are gathered and systematically organized in terms of their responsibilities, roles, duties, and interrelationships. The selection of the sample and the population for this study was based on a specific research design employed in previous studies on procurement (Rashid and Morledge, 1998; Love, 2002, Davis et al., 2009). During the process, only 151 replies were received (refer to Table 1). This number represents a $19 \%$ response rate. Among the respondents, 84 or $55.6 \%$ indicated their involvement in public sector projects.

This research utilizes the two stages of data collection applied by Mbachu and Nkado (2006), Tabish and Jha, (2011), and Adnan et al. (2008). Aside from using a quantitative approach, a semi-structured interview was conducted with 10 industry players. The objective of this interview is to obtain in-depth information to support the first quantitative result. Face-to-face interviews for the first phase of the quantitative data collection method were conducted with those who signified their willingness as expressed in the returned questionnaires. Each interview session was recorded and consequently transcribed. The names of the interviewees and the firms who participated in these interviews are not disclosed in this thesis to maintain confidentiality. The interview involves three public sector clients, five consultants, and two private clients.

\section{Analysis}

\section{Background of the Respondents}

The majority (51\%) of the respondents have college degrees. Respondents with qualifications below degree level (i.e., diploma and high school) accounted for $42.5 \%$, whereas $7 \%$ stated that they have a higher degree level. In terms of specialization or work expertise, $27.4 \%$ of the respondents specialized in quantity survey and construction, and $24.7 \%$ were experts in civil engineering. A number of respondents hold current positions as project managers $(27.4 \%)$ and quantity surveyors (23.3\%). The rest are civil engineers, site managers, and architects. Only a

Jaafar, M and Radzi N M (2013) 'Level of satisfaction and issues with procurement systems used in the Malaysian public sector', Australasian Journal of Construction Economics and Building, 13 (1) 50-65 


\begin{tabular}{|l|c|c|c|c|c|c|c|}
\hline \multicolumn{1}{|c|}{ Profession } & Contractor & Architect & Engineer & $\begin{array}{c}\text { Quantity } \\
\text { Surveyor }\end{array}$ & $\begin{array}{c}\text { Private } \\
\text { Client }\end{array}$ & $\begin{array}{c}\text { Public } \\
\text { Client }\end{array}$ & $\begin{array}{c}\text { Project/ } \\
\text { Contract } \\
\text { Manager }\end{array}$ \\
\hline $\begin{array}{l}\text { Source of } \\
\text { info }\end{array}$ & $\begin{array}{c}\text { CIDB } \\
\text { Malaysia, } \\
\text { Contractor } \\
\text { Grade 7 }\end{array}$ & $\begin{array}{c}\text { PAM Web } \\
\text { site }\end{array}$ & $\begin{array}{c}\text { IEM Web } \\
\text { site }\end{array}$ & BQSM & $\begin{array}{c}\text { REHDA } \\
\text { Directory } \\
\text { 2004/2005 } \\
\text { Web site }\end{array}$ & $\begin{array}{c}\text { Mousing and } \\
\text { Local } \\
\text { Government } \\
\text { Web site }\end{array}$ & $\begin{array}{c}\text { Ministry of } \\
\text { Finance }\end{array}$ \\
\hline $\begin{array}{l}\text { No. in the } \\
\text { directory }\end{array}$ & 4285 & 4972 & 9674 & 2081 & 1183 & 150 & 9 \\
\hline $\begin{array}{l}\text { No. of } \\
\text { questionnair } \\
\text { es sent }\end{array}$ & 200 & 100 & 100 & 100 & 150 & 150 & 9 \\
\hline $\begin{array}{l}\text { No. response } \\
\text { sample }\end{array}$ & 57 & 15 & 20 & 13 & 21 & 16 & 9 \\
\hline$\%$ response & $28 \%$ & $15 \%$ & $20 \%$ & $13 \%$ & $14 \%$ & $11 \%$ & $100 \%$ \\
\hline
\end{tabular}

Table 1 Response rate by profession

small number $(6.8 \%)$ of respondents have worked in the Malaysian construction industry for 20 years and above, whereas the rest have less than 20 years of work experience in the industry. Most of those interviewed have the same length of experience in the construction industry, which is between six and 20 years. The respondents of this study were divided into three categories: contractor firms (44\%); consultant firms (48\%), which include architects, quality surveyors, civil engineers, and project managers; and public client firms (11\%). Overall, the number of respondents who replied comprises the following: 10.7\% (Public clients), 13\% (Quantity Surveyor), private client (14\%), architect (15\%), engineer (20\%), contractors (28\%), and public clients (100\%). Public clients include government departments involved in projects such as the Public Work Department, local authorities, and state development companies. A test of differences that was conducted did not show a different result among the different characteristics of the respondents.

\section{Analysis of the Dominant Procurement System used}

The respondents were asked to tick the type of procurement method that they normally use. The five procurement systems included were the LSDS, LSBQ, and LSABQ systems, whereas the alternative procurement systems were the D\&C and Turnkey systems. Results of the survey concluded that the LSDS system was the most used procurement system with a total usage of $50.7 \%$. The LSBQ system garnered the second highest score of $34.2 \%$, followed by the Turnkey system with a total usage of $23.3 \%$ and the LSABQ system with a total usage of $20.5 \%$. The D\&C system ranked fifth with a total usage of $16.4 \%$.

The procurement system used in the industry is mainly based on the traditional system. However, the client can choose the implementation medium based on their requirements and type of project. For example, the LSDS system can be chosen because it can be subject to "no more measurement," where the client claims that a quantity surveyor can make a mistake in his calculations. On the other hand, another client prefers to use the LSBQ system. He said, "[proposing a] lump sum [following] the drawing is difficult because in most projects, the drawing is incomplete." The same experience is shared by another public client, who claimed that "[being] involved in different types of projects require different practice[s]; for example, infrastructure work use bill of quantity, [while] building work will use semi bill of quantity."

Jaafar, M and Radzi N M (2013) 'Level of satisfaction and issues with procurement systems used in the Malaysian public sector', Australasian Journal of Construction Economics and Building, 13 (1) 50-65 
In relation to the choices, a public client prefers to use the traditional systems, that is, either LSBQ or LSDS, for a number of reasons. First, they have a limited staff, and they can appoint consultants, call for tender, and award the project to a contractor. Second, the client can be assured of the design, quality, and time because a separate stage will enable consultants to understand fully the client's requirement in terms of planning and design as well as other factors such as profit and other services that need to be established. Finally, the client can choose the project team based on their track record.

One consultant stated his opinion: "In Malaysia, there [is] a [variety] of hybrid systems where [modifications] of [the] conventional system, variation of design and build, and management contracting [were observed]. These [occurred] under the previous leadership when we are geared toward [Malaysia's] incorporation and privatization." Aside from the prevalence of the traditional system, the current procurement practice in Malaysia remains undefined, as confirmed by an architect consultant, who claimed that in his project, the procurement system that was initially used was D\&C although a PMC was also appointed. This case happened when the main company has its own subsidiary company involved in the construction. He said: "In my case, the main company will join [sic] venture with another company, which is [a] renowned giant political company, for a proposal to construct a new school building. This company will appoint [the] PMC to handle all the consultants and [to] appoint contractors. There is a need to hire the expert PMC because we are using [the] Industrialized Building System (IBS) System where the supplier of the IBS system comes from their subsidiary company. There is an advantage because they know the system and can give advice on the technical system."

A more modern system is chosen for a client who has particular requirements. For example, when the manufacturer has a specific building plan that is subject to a disclosure of information or when the budget needs to be completed in a stipulated time, then the fast-track system will be appropriate. In assessing the applicability of the modern procurement system, the D\&C system is currently popular in Malaysia because of its sole responsibility. "In [reality], for D\&C [projects], [a] client will appoint the contractor. [The] contractor will appoint the consultant [based on the client's requirements]. All the consultants will cooperate with [the] contractor in preparing the drawing. The major role will be played by an architect who will design all the [buildings] and [facilities]. During the construction stage, the architect has to play the role of [supervisor] to ensure the quality of the project," said one contractor. Another respondent who has considerable experience in building projects further explained, "Definitely, it would save time, cost, and quality subject to the expertise and capability of the main contractor. For example, [the] modern procurement system will be applied for a complex project that not everyone has the expertise [for]. Like [a] hospital building- there are many specific room[s] and equipment such as [the] Operation Theatre and so on. [The] traditional system [is] always [faced with] problems [in coordinating with the] mechanical and electrical (M\&E) contractor, but under [the] $D \& C$ system, the M\&E contractor is under the main contractor. [Thus], the main contractor can fully monitor their performance".

\section{Analysis of the Problems with the dominant Procurement System}

Based on the literature discussed in Section 2, nine measures on procurement problems have been identified. A reliability test was conducted on the items of each variable to obtain the Cronbach Alpha (Table 2). The cut-off point of the Cronbach Alpha value was sufficiently reliable at 0.7 for the five-point scale measurement.

Table 3 suggests that disputes and capabilities are among the major problems encountered in all types of procurement systems. Meanwhile, operation and quality were rated as minor problems by the public sector. For the LSDS system, the major problems ranked by

Jaafar, M and Radzi N M (2013) 'Level of satisfaction and issues with procurement systems used in the Malaysian public sector', Australasian Journal of Construction Economics and Building, 13 (1) 50-65 
respondents were as follows: dispute, with a mean value of 3.54; cost, with a mean value of 3.39; and risk, with a mean value of 3.36. For the LSBQ system, dispute was chosen as the major problem with a mean value of 3.62 , followed by time (mean $=3.42$ ) and capabilities (mean = 3.29). Respondents agreed that dispute was a major problem in the LSABQ system, as well as dispute (mean $=3.53$ ), followed by capabilities (mean $=3.30$ ) and cost (mean $=3.25$ ). For the Turnkey system, time was rated as a major problem (mean $=3.59$ ), followed by dispute (mean=3.56) and capabilities (mean = 3.50). Finally, for the D\&C system, the major problem indicated was dispute (mean $=3.96)$, followed by management (mean $=3.65$ ) and capabilities $($ mean $=3.56)$.

\begin{tabular}{|c|c|}
\hline Problem variable & Measures \\
\hline Legal & $\begin{array}{l}\text { Conflict with contract terms } \\
\text { Bias toward one party } \\
\text { Misrepresentation of contract conditions } \\
\text { Uncertain scope of work in the contract } \\
\text { Inconsistency of the amendments in the contract } \\
\text { Alpha value }=0.815\end{array}$ \\
\hline Management & $\begin{array}{l}\text { Lack of management resources to organize and manage changes } \\
\text { Lack of management agreement toward a common team vision } \\
\text { Difficulty in design management } \\
\text { Lack of comprehensive briefing } \\
\text { Alpha value }=0.768\end{array}$ \\
\hline Capability & $\begin{array}{l}\text { Inadequate experience of contractors in the design process } \\
\text { Client's lack of knowledge } \\
\text { Procurement requires skillful consultants } \\
\text { Lack of resources and expertise in consultancy } \\
\text { Alpha value }=0.700\end{array}$ \\
\hline Dispute & $\begin{array}{l}\text { Problems with conflicts of interest in terms of cost reduction and securing design } \\
\text { Insufficient communication between parties } \\
\text { Alpha value }=0.700\end{array}$ \\
\hline Time & $\begin{array}{l}\text { Insufficient time to prepare tender document } \\
\text { Insufficient time allocated for briefing } \\
\text { Alpha value }=0.706\end{array}$ \\
\hline Risk & $\begin{array}{l}\text { Enhancing risk } \\
\text { Unmanageable risk } \\
\text { High risk of disparity between design and operational needs } \\
\text { Alpha value }=0.827\end{array}$ \\
\hline Operation & $\begin{array}{l}\text { Difficulties in managing the development process } \\
\text { Less control of the development process } \\
\text { Alpha value }=0.830\end{array}$ \\
\hline Cost & $\begin{array}{l}\text { High total project cost } \\
\text { Efficient in theory but expensive in practice } \\
\text { High maintenance cost } \\
\text { Cost uncertainty in the contract } \\
\text { High upfront capital } \\
\text { Alpha value }=0.795\end{array}$ \\
\hline Quality & $\begin{array}{l}\text { Less design control } \\
\text { Lower quality satisfaction } \\
\text { Alpha value }=0.700\end{array}$ \\
\hline
\end{tabular}

Table 2 Cronbach Alpha for problems of procurement

In the entire system given above, dispute was ranked the highest. According to one consultant, the practice in the industry is confusing because the system tends to be a hybrid one. In

Jaafar, M and Radzi N M (2013) 'Level of satisfaction and issues with procurement systems used in the Malaysian public sector', Australasian Journal of Construction Economics and Building, 13 (1) 50-65 
practice, the implementation of public procurement is influenced by factors such as the involvement of political influence in project awarding and implementation, as well as multilayered subcontracting. According to one client, "the [t]raditional contract has a gap, [as in] the involvement of political [parties] in project implementation. [The] [l]ack of supervision can [yield] many project dispute[s] and failures." The client then further explained that "in public sector procurement, [the] traditional system [leads] people or firms who [are] not experts to go for tender and win the project, then subcontract the whole project to another contractor or subcontractor." According to an experienced public client, a multi-layer subcontractor raises the issue of payment: "There are many cases where the main contractor uses the progress payment and does not [pay] the subcontractor. When the client is having problems with the progress, the project needs to be saved. It is more complicated if the project has been charged to the bank to [obtain] [a] bank loan. There is a case where the payment was paid [directly] to [the] bank and the balance [goes] to [the] subcontractor, with the agreement of the main contractor."

On the D\&C system, respondents commented on the risk involved in awarding the contract to a subcontractor. Another client comments that "the management [and] the implementation are [[performed] by [different groups of] people, and they appoint subcontractors based on the lowest price. With [the] lowest price, less supervision will result [in a] low-quality project. Normally, $60 \%$ of the total [physical] project will be sublet to a subcontractor. We have a problem of the practice of contractors in the industry and lack of skilled workers." The disadvantages will be the quality of the D\&C project, which is normally lower than that of the traditional system, because according to the client, a D\&C project contractor maximizes the profit by not paying the consultant on time.

\begin{tabular}{|c|c|c|c|c|c|c|c|c|c|c|}
\hline \multirow{3}{*}{ Problems } & \multicolumn{6}{|c|}{ Traditional } & \multicolumn{4}{|c|}{ Alternative } \\
\hline & \multicolumn{2}{|c|}{ LSDS } & \multicolumn{2}{|c|}{ LSBQ } & \multicolumn{2}{|c|}{ LSABQ } & \multicolumn{2}{|c|}{ Turnkey } & \multicolumn{2}{|c|}{$D \& B$} \\
\hline & Mean & Rank & Mean & Rank & Mean & Rank & Mean & Rank & Mean & Rank \\
\hline Mean Legal & 3.16 & 8 & 3.04 & 6 & 2.99 & 7 & 2.94 & 9 & 3.22 & 6 \\
\hline Mean Management & 3.21 & 7 & 3.27 & 4 & 3.22 & 5 & 3.28 & 5 & 3.65 & 2 \\
\hline Mean Capabilities & 3.27 & 6 & 3.29 & 3 & 3.30 & 2 & 3.50 & 3 & 3.56 & 3 \\
\hline Mean Dispute & 3.54 & 1 & 3.62 & 1 & 3.53 & 1 & 3.56 & 2 & 3.96 & 1 \\
\hline Mean Time & 3.30 & 5 & 3.42 & 2 & 3.23 & 4 & 3.59 & 1 & 3.29 & 5 \\
\hline Mean Risk & 3.36 & 3 & 3.01 & 7 & 3.13 & 6 & 3.10 & 6 & 3.19 & 7 \\
\hline Mean Operation & 3.28 & 4 & 2.58 & 9 & 2.83 & 8 & 3.00 & 7 & 3.13 & 8 \\
\hline Mean Cost & 3.39 & 2 & 3.11 & 5 & 3.25 & 3 & 3.38 & 4 & 3.38 & 4 \\
\hline Mean Quality & 2.96 & 9 & 2.98 & 8 & 2.80 & 9 & 2.97 & 8 & 2.96 & 9 \\
\hline
\end{tabular}

Table 3 Non-parametric test on problems of procurement

Note: Less than $1.49=$ strongly disagree; $1.5-2.49=$ disagree; $2.5-3.49=$ either agree or disagree; $3.5-4.49=$ agree; and 4.5-5.0 = strongly agree

Table 4 shows the mean scores on the satisfaction level of the public sector. The level of satisfaction of the respondents was shown to be only in the medium level, with mean values from 1.5 to 2.5. The LSBQ system garnered the highest satisfaction level with mean $=2.48$, followed by the $D \& C$ (mean $=2.32$ ) and $A B Q$ (mean $=2.26$ ) systems.

Jaafar, M and Radzi N M (2013) 'Level of satisfaction and issues with procurement systems used in the Malaysian public sector', Australasian Journal of Construction Economics and Building, 13 (1) 50-65 


\begin{tabular}{|c|c|c|}
\hline Procurement types & Mean & Std. Deviation \\
\hline LSDS & 2.13 & 0.489 \\
\hline LSBQ & 2.48 & 0.509 \\
\hline ABQ & 2.26 & 0.449 \\
\hline D \& B & 2.32 & 0.671 \\
\hline Turnkey & 2.14 & 0.639 \\
\hline
\end{tabular}

Table 4 Mean value of the respondent's level of satisfaction

Mean ranging from 1.00 to $1.50=$ low; mean ranging from 1.50 to $2.50=$ medium; and mean ranging from 2.50 to $3.00=$ high

The satisfaction level is based on the final product produced. However, each client mentioned that the satisfaction level is based on the capability of the main contractor, that is, regardless of the type of development, the success of a project depends on the main contractor. According to an experienced client, "[the] success or failure of the project very much [depends] on the capability of [the] contractor." All the parties interviewed mentioned the incompetence of contractors as the main issue affecting project delivery and overall satisfaction.

\section{Discussion}

Earlier literature has raised the importance of the choice of procurement system in ensuring project success (Eriksson and Laan, 2007). Thus, numerous studies have been conducted in different countries to identify the issues with the various procurement systems. A two-stage method was conducted in this study to capture the dominant procurement system in the industry, the problems associated with such system, and the satisfaction level of the industry players. The results revealed that the traditional procurement system remains dominant, with LSDS as the highest ranking system, followed by LSBQ and LSABQ. According to Davis et al. (2009) and Love et al. (2010), the traditional lump sum has been the primary procurement method in Australia. Even Davis et al. (2009) argue that the system is beginning to change because of the evolution of new and hybrid procurement systems. Malaysia has also begun using new and hybrid procurement methods, as highlighted by Cho et al. (2010). The push for the adaptation of new procurement methods is justified by the need for higher client satisfaction (Mbachu and Nkado, 2006) and improved cycle-time performance (Gibson et al., 2007). Hale et al. (2009) and Migliaccio et al. (2012), along with players from the industry, claim that the D\&C system saves time and is suitable for complex projects. However, the fast-track approaches are not without problems (Cho et al., 2010).

The choice of procurement is more related to a client's familiarity and knowledge regardless of any differences in the projects (Eriksson and Westerberg, 2010). For example, a respondent states that "our practice of D\&C here is very much different from the UK, and the industry tends to modify the system to suit their requirements, which are closely related to their past experiences and knowledge." This statement justifies the term "hybrid procurement," which is widely practiced in the Malaysian construction industry. "We can have different terms for different procurement systems but the practice is rather similar," explained one consultant respondent.

Based on the ranking of the five procurement systems, this study explored related problems from the perspective of the public sector. Based on the mean value, industry players generally

Jaafar, M and Radzi N M (2013) 'Level of satisfaction and issues with procurement systems used in the Malaysian public sector', Australasian Journal of Construction Economics and Building, 13 (1) 50-65 
agreed that the main problems with both traditional and alternative procurement systems are dispute, capability, time, and cost. In a comparison between traditional and alternative procurement methods, the major results indicate that:

1. D\&C received the highest agreement on dispute, followed by other procurement methods;

2. Capability problems received a higher agreement in D\&C and Turnkey projects compared with the traditional procurement methods LSBQ and LSDS;

3. The time problem in Turnkey projects received the highest agreement, followed by LSBQ and D\&C systems; and

4. Cost is the main concern for Turnkey, D\&C, and LSDS projects.

The above evidence strengthens the argument that the move to use alternative procurement systems is not a guarantee that the deficiencies of the traditional system will be overcome (Cho et al., 2010). Interestingly, dispute was proven to be a major problem in both systems. Disputes are associated with a conflict of interest, such as the need to reduce costs and secure a design (Smith et al., 2004) as well as insufficient communication between parties (Yu et al., 2005; Ling and Poh, 2008; CIOB report, 2010). Consequently, Ofori (2007) argues that any dispute is likely to be costly and disruptive to the project unless it is resolved early. As explained by one consultant, "in most cases, our contract relationship is [unclear], thus [leading] to many disputes and discrepancies [in the] contract." These results support previous reports (Yu et al., 2005; The $\mathrm{CIOB}, 2010)$ that categorized dispute as a major problem in the implementation of procurement systems in different countries.

Disputes under $D \& C$ received the highest agreement (mean $=3.96$ ) because $f$ the uncertainty of drawing, which yields numerous problems in project management, as proposed by Cho et al. (2010). However, in traditional systems, Tien and Jason (2006) found that variations also cause disputes among various parties, thus resulting in cost uncertainty with changes in design and scope. Insufficient design could be a reason for disputes in LSDS and LSBQ projects. For example, Neighbour (2000) stressed the importance of sufficient time for the consultants' preparation of the full document prior to calling for tenders. Tabish and Jha (2011) identified that pre-project planning and a clear scope to be among the factors that contribute to the success of a public construction project. However, a study by Jaafar and Chong (2010) acknowledged the lack of attention given to public projects during the briefing stages. Similarly, Rwelamila and Mayor (1999) agree that a lack of preparation for the design and bills of quantities before the selection of contractors is evident. Changes in drawing would affect the measurement of the triangle project performance because the industry involves numerous parties in temporary project organizations. Inadequate and inefficient communication between parties could lead to a lack in information flow. A survey conducted in the United Kingdom mentioned lack of communication as the most significant problem in the procurement process, with dispute as the major problem in traditional and alternative procuring methods (The CIOB, 2010). Similarly, Smith et al. (2004) concluded that poor communication and misunderstanding between contracting parties could result in contractual disputes. In this study, all the interviewed respondents highlighted multi-layered subcontracting as a major issue resulting in inefficient communication, lack of integrity, and problems in payment.

Meanwhile, the problem of capabilities was highlighted as a major issue in managing alternative procurement systems, especially in the D\&C system. In conducting a D\&C project, Puerto et al. (2008) expressed the need to appoint a highly capable and qualified team to ensure the success of the project. However, traditional procurement systems also suffer from the lack of capabilities of the people in charge. A lack of experience among the construction team can cause delays and can result in longer construction time. Ofori (2007) and Harland (2005) argued

Jaafar, M and Radzi N M (2013) 'Level of satisfaction and issues with procurement systems used in the Malaysian public sector', Australasian Journal of Construction Economics and Building, 13 (1) 50-65 
against the lack of capability of the public procurement officer when handling a public project. According to Ofori (2007), the lack of skills among procurement officers during public procurement is an obstacle to any effort to promote innovation. Furthermore, Harland (2005) raised the issue of a shortage of highly qualified and motivated professionals during public procurement. As mentioned by one respondent, "our clients and consultants are not capable enough to handle the project, and [the] public sector needs to enhance their effectiveness in project supervision." On the other hand, the capability of the contractor and consultant is a major concern among industry players. As highlighted by the CIOB (2010), the industry players have a poor understanding of procurement systems. In Malaysia, the procurement system has not been widely understood by the industry, except for quantity surveyors and experienced architects.

In developing countries, construction projects are closely related to the political agenda (Ofori, 2007). For example, in Western Australia, Love et al. (2008) find that LSDS methods are always effective and cost-efficient, but clients prefer different procurement systems for complex projects. In reality, the local market has limited experience dealing with construction management procurement. Client's experience and current market conditions influence the choice of procurement strategy. For example, the interviewed respondents raised the issue of procurement implementation in Malaysia. Regardless of the procurement system adopted, political influence in awarding public projects contributes to the increase in the number of contracting firms that are only interested in obtaining contracts. These firms sublet the total project to other contractors or subcontractors. Other issues have been mentioned by the respondents, such as incapability of contractors, which results in project mismanagement; manipulation of payments; difficulties in obtaining supplies on time; as well as lack of integrity and commitment. These issues are proven by the project's quality where it has been given minor attention, indicating the unimportance of procurement issues in solving industry problems. The important role of contractors has been highlighted by Rwelamila and Meyer (1999). These issues also arise in both traditional and modern systems.

Regarding the problem of time, respondents agree that this problem exists in all types of procurement methods, with the highest agreement cited for the Turnkey system. Time is closely associated with cost. The first part of the introduction noted that numerous projects suffer from additional time and costs in Malaysia. A fast-track system, as highlighted by Cho et al. (2010), needs to be managed by a capable team. While traditional methods have been tied-up with a sequential process, a fast-track system is closely associated with a lengthened process of project delivery. LSBQ has been agreed to be late compared with LSDS because additional time is required for the preparation of the bills of quantities (Turner, 1983). Furthermore, project delivery in this system provides little opportunity for interaction and teambuilding among the members of the construction team. According to Soon (2010), various parties such as PWD, IEM, PAM, CIDB, and even the federal government have exerted efforts to establish of the rules and standards on work implementation to resolve delay issues. With a mean of 3.29 , the majority of respondents acknowledged the effectiveness of the D\&C system in ensuring timely project delivery, supporting the propositions of Gibson et al. (2007) and Migliaccio et al. (2010). Given that D\&C is the most popular alternative procurement system in Malaysia, industry players are starting to become familiar with its implementation. Cost problems, on the other hand, moderately exist in all types of procurement, with high agreement on the LSDS, Turnkey, and D\&C. Problems of conflict of interest in terms of reducing cost, securing design, and insufficient communication between parties could yield more problems that can delay the project.

Jaafar, M and Radzi N M (2013) 'Level of satisfaction and issues with procurement systems used in the Malaysian public sector', Australasian Journal of Construction Economics and Building, 13 (1) 50-65 
The problem of quality is one of the minor problems encountered in all types of procurement. Although the issue of the public sector's building quality was highlighted, the study findings indicate that the industry practitioners are not significantly concerned about quality compared with the other two performance measurements, which are time and cost. These findings contradict the previous literature, which indicates that time, cost, and quality are among the major problems of procurement systems. This result is also in contrast to previous literature on various procurement systems, which incorporate the quality issue with other dominant problems such as time and cost (Chang, 2003; Turk, 2006; Toor and Ogunlana, 2008; The ClOB report, 2010; Rahman et al., 2010). Turk (2006) mentioned that quality is a serious problem in Turkey, given that the industry has to sacrifice by cutting costs or shortening project time. The quality problem is also critical in construction projects in China (Chang, 2003).

Based on the satisfaction level of the procurement system used by the public, all the procurement systems were given a medium level of satisfaction. This study supports previous findings by Mbachu and Nkado (2006). Hashim (1997) found that 54\% of the clients in Malaysia are satisfied with the completion rate of projects that employ traditional procurement methods. Respondents expressed the highest satisfaction with the LSBQ and D\&C systems. The LSBQ can reduce the cost of tendering (Australian Institute of Quantity Surveyors, 2001) because the $\mathrm{BOQ}$ encourages a greater number of subcontractors to submit tenders for work packages. Davis et al. (2009) include among the list of the benefits of the LSBQ method the certainty of progress payment, providing common basis for change order management, and minor errors. Furthermore, the industry in Malaysia has used the LSBQ method for many years. However, the public sector has adopted the D\&C system since the 1990s. Thus, familiarity with the system justified the high satisfaction rating, especially for a complex project, as highlighted by a respondent: "the procurement selection is done by clients and they tend to use the normal procurement or modify the new procurement according to their norms." In relation to procurement selection for the public sector, Ofori (2007) stated that in developing countries, bureaucracy leads to more levels of administrative procedures and approval checks, causing inefficiencies, high costs, and project delays. Toor and Ogunlana (2008) added that this bureaucracy could result in the fragmentation of procurement laws, higher levels of corruption, and a lack of coherence among the procurement systems, the local culture, administrative systems, and the authority structure. The respondent also mentioned the uncontrolled political interruptions in public organizations, which impede the effectiveness of project implementation. Even clients tend to choose a procurement system that they are highly familiar with, but Dubois and Gadde (2002) argue that changes in attitudes, behavior, and procedures can help increase the chances of project success.

\section{Conclusion}

This study identified the dominant procurement system, the problems associated with it, and the satisfaction levels of the public procurement systems in the Malaysian construction industry. Public sector clients select the LSDS system as their main choice among the traditional procurement systems used in accomplishing projects in Malaysia. The move to use both alternative and traditional procurement systems by the private sector in other countries has convinced them of the need to adopt alternative procurement systems to accelerate the development of the country. Throughout the industry's development, however, the suitability and efficiency of alternative procurement systems are being questioned, considering the various defects observed in public projects.

This study found that no specific procurement system is the best because each system has its own flaws. The problems could also lie with the industry players, who might have limited knowledge on the procurement process. Another observation from this study is that the public

Jaafar, M and Radzi N M (2013) 'Level of satisfaction and issues with procurement systems used in the Malaysian public sector', Australasian Journal of Construction Economics and Building, 13 (1) 50-65 
sector has been practicing the same working culture from generation to generation. Their familiarity and knowledge of the traditional procurement system has been embedded in their working culture, which explains the barriers to change. This factor highlights the importance of the traditional LSBQ and LSDS systems in the industry.

Even though there has been a massive development of procurement systems worldwide, this study found that the procurement system applied in the Malaysian construction industry has not changed greatly since the time of British rule. The same situation has also been observed in other developing economies. Generally, in developing countries, the public sector is the biggest client to the construction industry, but unfortunately a high tendency exists for political involvement and cronyism. With the large number of stakeholders, certain groups of people tend to manipulate the procurement system for their own advantage. This situation may lead to bias in the awarding of contracts and project implementation. The actual procedure may not be followed, which results in the shift to a hybrid system. Such a shift can yield problems related to disputes, reduced capabilities in project management, and negative impacts on time and cost. There is a move towards advanced procurement delivery processes practiced in the industry to suit industry requirements such as industrialised building systems and e-procurement however the industry's working culture still remains the same. Therefore, the development of procurement system in Malaysia has been very slow besides numerous achievements on the procurement research in Western countries. In different perspective, this article highlights the importance of human factor in managing the procurement process. Procurement transformation would enquire the transformation of the mindset and working culture of the entire industry participant. CIDB needs to increase the industry awareness on the importance of getting the right procurement in order to enhance the stakeholder's satisfaction in relation to industry changes and requirement.

This study is only based on a small group of respondents where the actual knowledge on procurement systems is unknown. A thorough study of the procurement issue, which can be performed by interviewing experts in the industry, is needed to identify actual barriers to come up with a better procurement solution. A study on the private sector's procurement methods could be another option because this sector has contributed much in terms of modifying the procurement system to ensure successful project completion. Therefore, a continuous study on procurement systems as a green issue should be conducted, alongside the necessary changes in the industry.

\section{References}

Adnan, H., Jusoff, K. \& Salim, M. K, (2008) 'The Malaysian Construction Industry's Risk Management in Design and Build', Modern Applied Science, 2 (5), 27-33

Ashworth, A. (1991) Contractual Procedures in the Construction Industry (2nd ed), Longman Scientific and Technical Group, Harlow UK

Australian Institute of Quantity Surveyors-AIQS (2001) 'Guaranteed bills of quantities', discussion paper, 25 August, 2000, letter, 1-7

Chan, A.P.C., Scott, D., and Lam, E.W.M., (2002) Framework of Success Criteria for Design/Build Projects, Journal of Construction Engineering and Management, 18 (3), 120-128

Chang, A. (2003) 'Many buildings in China are depth traps for firefighters', Association for Asian Research Journal, 14 November

Chartered Institute of Building (CIOB) UK (2010) 'Procurement in the Construction Industry', available at 
http://www.ciob.org.uk/sites/ciob.org.uk/files/Procurement\%20in\%20the\%20Construction\%20In dustry.pdf (accessed Sept 2011)

Cho, K. M., Hyun, C. T., Koo, K. J. and Hong, T.H. (2010) 'Partnering process model for publicsector fast-track design-build projects in Korea', Journal of Management in Engineering, 26 (1), 19-29

Construction Industry Development Board (CIDB) Malaysia (2006) 'Procure 2010; Manual to Guide Infrastructure Development for the Soccer World Cup - Manual 4: Best Value Procurement', available at http://www.docstoc.com/docs/69793224/CIDB-Annual-Report-2006--Text (accessed 2 October 2011)

Construction Industry Development Board (CIDB) Malaysia (2009) Malaysia Country Report, The International Conference 2010, Housing and Real Estate Market Development -Worldwide Experience and Options for Vietnam

Davis, L. (1995) 'Doing your homework', Design and Build. 7 July, 29-30

Davis, P.R., Love, P.D.P and Baccarini, D. (2009) 'Bills of Quantities: nemesis or nirvana?', Structural Survey, 2 (27), 99-108

Dubois, A. \& L-E Gadde (2002) 'The construction industry as a loosely coupled system: implications for productivity and innovation', Construction Management and Economics, 20 (7), 621-631

El Wardani, M., Messner, J., \& Horman, M. (2006) 'Comparing Procurement Methods for Design-Build Projects', Journal of Construction Engineering and Management, 132 (3), 230-238

Eriksson, P.E. \& Laan, A. (2007) 'Procurement Effects on Trust and Control in Client-Contractor Relationships', Engineering, Construction and Architectural Management, 14 (4), 387-399

Eriksson, P.E \& Westerberg, M. (2010) 'Effects of cooperative procurement procedures on construction project performance. A conceptual framework', International Journal Project Management, doi:10.1016/j.jproman.2010.01.003

Gibson, G.E., O'Connor, J.T., Migiaccio, G. \& Walewski, J. (2007) 'Alternative project delivery, procurement and contracting methods for highways', Key implementation issues and lessons learned with design-build projects, ASCE Construction Instituite, Reston, Va., 1-1

Gould, F. E., (1997) Managing the Construction Process: Estimating, Scheduling and Project Control, Simon \& Schuster/A Viacom Company, Upper Saddle River, New Jersey, USA

Hale, D.R., Shrestha, P.P., Gibson, G.E., \& Migliaccio, G.C., (2009) 'Empirical comparison of Design/Build and Design/Bid/Build project delivery methods', Journal of Construction Engineering and Management, 135 (7), 579-587

Hamzah, H. (2003) Future Prospects for Project Management in the Malaysian Construction Industry, Universiti Malaya, Kuala Lumpur

Harland, C.M., Bakker, E.F., Caldwell, N.D., Phillips, W.E. \& Walker, H.L. (2005) The Changing Role of Public Procurement - Executive Report of the Second Workshop, International Research Study on Public Procurement. Bath, UK: Centre for Research in Strategic Purchasing and Supply, University of Bath School of Management

Hashim, M. (1997) 'Clients criteria on the choice of procurement systems-a Malaysian Experience:. In procurement- A Key to innovation', Canada: CIB Proceeding, 273-284

Hashim, M., Li, M.C.Y., Yin, N.S, Heng, S.M, \& Yong, T.L. (2006) 'Factors influencing the selection of procurement systems by clients', Conference on Construction Industry, Padang,

Jaafar, M and Radzi N M (2013) 'Level of satisfaction and issues with procurement systems used in the Malaysian public sector', Australasian Journal of Construction Economics and Building, 13 (1) 50-65 
Indonesia, $\quad$ http://www.fab.utm.my/download/ConferenceSemiar/ICCI2006S4PP12.pdf (accessed 2 October 2011)

Ibrahim, A.R., Roy, M.H., Ahmed, Z. \& Imtiaz, G. (2010) 'An investigation of the status of the Malaysian construction industry', Benchmarking: An International Journal, 17 (2), 294-308

Imtiaz, G. and Ibrahim, A.R. (2005) 'Lean production system in project delivery: the way forward for Malaysian construction industry', Proceedings of Kuala Lumpur Quantity Surveyor International Convention (QSIC), Kuala Lumpur

Jaafar, M. \& Aziz, A.R.A. (2009) 'Procurement reform in public sector governance: A timely necessity', The Malaysian Surveyor, 44 (2), 25-29

Jaafar, M. \& King, A.R.A (2011) 'Construction Briefing Process in Malaysia: Procedures and Problems in the Public Sector', International Journal of Information Technology Project Management (IJITPM), 2 (2), 11-22

Jaafar, M. \& Radzi, N. (2012) 'Building procurement in a developing country: a comparison study between public and private sectors', International Journal Procurement Management, 5 (5), 608-626

Kong, Ann Tien \& Gray, Jason (2006) 'Problems With Traditional Procurement in the Malaysian Construction Industry - a Survey. In Runeson, Goran and Best, Rick, Eds', Proceedings Australasian Universities Building Educators Association Annual Conference, University of Technology, Sydney, 1-21

Ling \& Poh (2008) 'Problems encountered by owners of design-build projects in Singapore', International Journal of Project Management, 26 (2), 164-173

Liu, A.M.M. \& Walker, A. (1998) 'Evaluation of project outcomes', Construction Management and Economics, 16 (2), 209-19

Love, P.E.D. (2002) 'Influence of project type and procurement method on rework costs in building construction projects', Journal of Construction Engineering and Management, 128 (1), 18-29

Love, P.E.D., Edwards, D. J., Watson, H. \& Davis, P. (2010) 'Rework in civil infrastructure projects: Determination of cost predictors', Journal of construction Engineering and Management, March, 136 (3), 275-282

Mahmood, W.Y.W. \& Mansor, N. (1996) 'Quality Management in Construction Industry Malaysian Experience', Jurnal Ukur Bahan

Masterman, J.W.E. (2002) An introduction to Building Procurement Systems, Spon PR, London

Mbachu, J.I \& Nkado, R. (2006) Conceptual framework for assessment of client needs and satisfaction in the building development process', Construction Management and Economics, 24 (1), 31-44

Migliaccio, G.C., Bogus, S.M \& Chen, A. (2010) 'Effect of duration of Design-Build procurement on performance of transportation projects', Journal of the Transportation Research Board, 2151, 67-73

Neighbour, K. (2000) 'The clients' guide to construction projects: Best practices for the procurement and delivery of a project', RAIA, accessed at: http://aca.org.au/wpcontent/uploads/2009/12/a_guide_to_construction_projects_2006-publication_issue.pdf on 11th Oct 2012 
Nitithamyong, P. \& Tan, Z. (2007) 'Determinants for effective performance of external project management consultants in Malaysia', Engineering, Construction and Architectural Management, 14 (5), 463-478

Ofori, G. (2007) 'Procurement reform: A research agenda for construction in developing Countries', Proceeding of CIB World Building Congress, Cape Town, South Africa

Pratt, R. (2000) Project management in Malaysia, some ideas on the way ahead, paper presented at Asia Pacific Diligence Sdn Bhd seminar, Project management: strategies, techniques, operations and control, Kuala Lumpur, Malaysia

Puerto, C.L.D., Gransberg, D.D \& Shane, J.S (2008) 'Comparative analysis of owner goals for design/build projects', Journal of Management in Engineering, ASCE, 24 (1), $32-39$

Rahman, H.A., Wang, C. \& Yap, X.W. (2010) 'How professional ethics impact construction quality: Perception and evidence in a fast developing economy', Scientific Research and Essays, 5 (23), 3742-3749

Ramus, J., Birchall, S. \& Griffiths, P. (2006) Contract Practice for Surveyors (Fourth Edition), Elsevier, Great Britain

Rashid, R.A., Taib, I.M., Ahmad W.N.W, Nasid M.A, Ali, W.N.W. and Zainordin, Z.A. (2006) 'Effect of procurement systems on the performance of construction projects', available at http://eprints.utm.my/790/1/Procurement_performanceRosli.pdf (accessed Sept 2011)

Rashid, K.B.A., \& Morledge, R. (1998) 'Construction procurement processes in Malaysia: constraints and strategies', paper presented at the 14th Annual ARCOM Conference

Roodhooft, F. \& Abbeele, A.V.D. (2006) 'Public procurement of consulting services: Evidence and comparison with private companies', International Journal of Public Sector Management, 19 (5), 490-512

Rwelamila, P.D \& Meyer, C. (1999) 'Appropriate or default project procurement system', Cost Engineering, 41 (9), 40-44

Skitmore, R.M., \& Marsden, D.E. (1988) 'Which procurement system?, Towards a universal procurement selection technique', Construction Management and Economics, 6 (3), 71-89

Smith, J., Zheng, B., Love, P.E.D. \& Edwards, D.J. (2004) 'Procurement of construction facilities in Guangdong Province, China: factors influencing the choice of procurement method', Facilities, 22 (5), 141-148

Soon, T.K. (2010) 'Dispute resolution in relation to delay in construction project', unpublised Msc thesis, Faculty of Civil Engineering, Universiti Teknologi Malaysia

Tabish, S.Z.S., \& Jha, K.N. (2010) 'Identification and evaluation of success factors for public construction projects', Construction Management and Economics, 29 (8), 809-823

Toor, S.U.R. \& Ogunlana, S.O. (2008) 'Problems causing delays in major construction projects in Thailand', Construction Management and Economics, 26 (4), 395-408

Torbica, Z.M \& Stroh, R.C (2001) 'Customer satisfaction in home building', Journal of Construction Engineering and Management, 127 (1), 82-86

Turner, A. (1990) Building Procurement, Macmillan Education Ltd, London

Turk, A.M. (2006) 'ISO 9000 in construction: An examination of its application in turkey', Building and Environment, 41 (4), 501-511

Yu, A.T.W., Shen, Q., Kelly, J. \& Haunter, K. (2005) 'Application of value management in project briefing', Facilities, 23 (7/8), 330-34 